\title{
EVALUASI KEBERLANJUTAN PROGRAM PENGEMBANGAN KAPASITAS SDM PENGENDALIAN KARHUTLA DENGAN METODE RAPFIRE
}

\author{
Sustainability Evaluation of Human Resource Capacity Development \\ Program of Forest and Land Fire Control using the Rapfire Method
}

\section{Mochamad Asep Maksum ${ }^{12}$, M. Syamsul Maarif3 ${ }^{3}$ Lailan Syaufina4 ${ }^{4}$ Diah Zuhriana²}

\begin{abstract}
Abstrak: Kebakaran hutan dan lahan (karhutla) di Indonesia sebagian besar disebabkan oleh faktor manusia, oleh karenanya sumber daya manusia (SDM) merupakan unsur penting yang perlu diperhatikan dalam pencegahan dan pengendalian karhutla. Salah satu upaya antisipasi karhutla yang senantiasa terjadi berulang di Indonesia adalah dengan menyiapkan sumber daya manusia yang memiliki kapasitas dalam pengendalian karhutla di lapangan. Beberapa program pengembangan kapasitas SDM pengendalian karhutla telah dikembangkan di Indonesia, namun dinilai belum berperan signifikan dalam mengendalikan karhutla di Indonesia. Penelitian ini bertujuan untuk mengevaluasi keberlanjutan program pengembangan kapasitas SDM yang telah berjalan selama ini dengan membangun dan menerapkan metode Rapfire melalui pendekatan multidimensional scalling. Hasil penelitian menunjukkan bahwa program pengembangan kapasitas SDM karhutla dengan kepesertaan masyarakat cenderung memiliki tingkat keberlanjutan yang rendah, oleh karenanya perlu mendapat prioritas pengembangan. Penelitian ini juga menemukan bahwa faktor pengungkit utama yang mempengaruhi tingkat keberlanjutan berada dalam dimensi input, mencakup sistem rekrutmen, kelembagaan pengelola program, dan sistem penganggaran. Faktor pengungkit merupakan atribut-atribut penting yang perlu diperhatikan dan mendapat prioritas kebijakan dalam rangka mempertahankan dan atau meningkatkan status keberlanjutan program pengembangan kapasitas SDM pengendalian karhutla di Indonesia.
\end{abstract}

Kata kunci: faktor pengungkit, kapasitas SDM, kebakaran hutan dan lahan, rapfire, status keberlanjutan

Abstract: Forest and land fires in Indonesia are mostly caused by human factors, therefore human resources are an important element that needs to be considered in the prevention and control of forest and land fires. One of the important efforts in anticipating the ongoing recurrence of forest and land fires in Indonesia is by preparing human resources who have the capacity to control the forest and land fires in the field. Several human resource capacity building programs to control forest and land fires have been developed in Indonesia, but are considered not to have played a significant role in controlling forest and land fires in Indonesia. This study aims to evaluate the

\footnotetext{
${ }^{1}$ Pengelolaan Sumber Daya Alam dan Lingkungan, Sekolah Pascasarjana, Institut Pertanian Bogor

${ }^{2}$ Balai Diklat Lingkungan Hidup dan Kehutanan Bogor

${ }^{3}$ Sekolah Bisnis, Institut Pertanian Bogor

${ }^{4}$ Fakultas Kehutanan, Institut Pertanian Bogor
} 
sustainability of the human resources capacity development program that has been running so far, by building and implementing the Rapfire method through a multidimensional scaling approach. The results of the study show that the forestry human resource capacity development program with community participation tends to have a low level of sustainability, therefore it needs to receive development priorities. The study also found that the main leverage factors that influence the level of sustainability are in the input dimension, including the recruitment system, program management institutions, and budgeting systems. Leverage factors are important attributes that need to be considered and get policy priorities in order to maintain or improve the sustainability status of the human resources capacity development program for forest and land fires control in Indonesia.

Keywords: forest and land fires, human resource capacity, rapfire, sustainability status, leverage factor

\section{PENDAHULUAN}

Kebakaran hutan dan lahan (Karhutla) di Indonesia sebagian besar disebabkan bukan oleh faktor alam, namun lebih banyak karena faktor manusia, baik yang dilakukan dengan sengaja maupun secara tidak sengaja (Akbar, Hadi, \& Sabarudin, 2011; Cattau et al., 2016; Darwiati \& Tuheteru, 2010; Khalwani, Bahruni, \& Syaufina, 2015; Qodriyatun, 2014; Saharjo, 2016; Syaufina, 2008). Dengan fakta bahwa aktivitas manusia yang menjadi penyebab utama, kejadian karhutla di Indonesia sangat mungkin untuk dapat dicegah dan dikendalikan, dan dalam hal ini sumber daya manusia (SDM) menjadi salah satu faktor kunci untuk pencegahan dan pengendaliannya.

Di Indonesia SDM yang memiliki tugas dan fungsi khusus dalam pengendalian karhutla saat ini dikelola oleh Kementerian Lingkungan Hidup dan Kehutanan (KLHK) dan Kementerian Pertanian (Kementan), terdiri atas SDM aparatur (Aparatur Sipil Negara dan tenaga kontrak) dan non aparatur (masyarakat/sukarelawan). Saat ini kapasitas SDM dalam pengendalian karhutla di Indonesia baik aparatur maupun non aparatur dinilai masih rendah. Hasil penelitian Sukrismanto, Alikodra, \& Saharjo (2011) mengindikasikan lemahnya kapasitas koordinasi antar organisasi dalam pengendalian kebakaran hutan/lahan di Indonesia, sehingga kejadian kebakaran hutan/lahan belum dapat terkelola dengan baik. Bantuan layanan di antara organisasi dalam pengendalian kebakaran belum efektif baik di tingkat nasional, provinsi maupun kabupaten/kota, sebagaimana diperkuat oleh hasil kajian Friskarini dan Kasnodihardjo (2013) di Provinsi Jambi, serta Meiwanda (2016) dan Harun (2016) di Provinsi Riau. Sementara itu untuk masyarakat, beberapa hasil penelitian turut mendukung asumsi bahwa kapasitas SDM masyarakat baik berupa kesadaran, pengetahuan, keterampilan dan kelembagaan masih menjadi salah satu faktor penting, baik dari sisi penyebab maupun peluangnya untuk berperan besar dalam upaya pengendalian karhutla (Evayanti \& Zulkarnaini, 2014; Muttaqin, Husin, \& Safrida, 2015; Nurdianto, Mardhiansyah, \& Oktorini, 2016). Terkait peran penting SDM dalam pengendalian karhutla di Indonesia dalam menjamin efektivitas dan jangkauan pengendalian karhutla, dalam Rencana Strategis Kementerian Lingkungan Hidup dan Kehutanan (KLHK) diantaranya telah ditetapkan peningkatan kapasitas terhadap sejumlah 5000 orang SDM pengendalian karhutla sebagai salah satu indikator kinerja Program Pengendalian Karhutla (KLHK, 2015). Peningkatan kapasitas SDM diantaranya dilakukan melalui pendidikan dan pelatihan, pembekalan, bimbingan teknis, transfer pengalaman melalui sarana informasi, jaringan dan advokasi (CaDRi, 2012; KLHK, 2016).

Pengembangan kapasitas tidaklah sekedar meningkatkan keterampilan individu dalam melaksanakan tugasnya. Pengembangan kapasitas, dapat dipahami sebagai pembelajaran keterampilan baru, sikap dan pengetahuan yang akan meningkatkan manusia dan modal sosialnya; sehingga kemungkinan mereka mampu menjadi aktor penggerak yang mampu membawa perubahan berkelanjutan dalam kehidupan mereka (Morgan, 
2016). Pengembangan kapasitas SDM yang diantaranya dilakukan melalui pelatihan seringkali menghasilkan peningkatan signifikan dalam pengetahuan dan keterampilan sesaat pasca pelatihan, namun hal tersebut tidak bertahan selamanya. Hilangnya kompetensi dari waktu ke waktu berkaitan dengan keterlambatan dalam menerapkan pembelajaran karena kurangnya dukungan mekanisme dan pola yang efektif, dan kurangnya dukungan organisasi (Monroe et al., 2013).

Evaluasi program pengembangan kapasitas SDM selama ini biasanya hanyalah terkait penggunaan anggaran ataupun output jumlah orang yang menjadi obyek program, dan belum secara terukur menyentuh aspek kualitas atau efektivitas program yang sudah berjalan. Evaluasi yang lebih bersifat rutinitas keproyekan tersebut karenanya tidak secara signifikan dapat memberikan masukan bagi perbaikan atau kesinambungan program yang telah dan sedang berjalan. Penelitian ini mengembangkan sebuah metode penilaian atau evaluasi cepat (rapid appraisal), dengan memodifikasi metode sejenis yang sebelumnya telah dikembangkan, untuk diaplikasikan dalam menilai keberlanjutan program pengembangan kapasitas SDM pengendalian karhutla. Keberlanjutan dalam hal ini diterjemahkan sebagai kemampuan program untuk dapat bertahan dalam rentang waktu panjang, terjaga efektivitasnya, serta berkembang kekuatannya sebagai tolok ukur keberhasilan (Ariyani, Fauzi, Juanda, \& Beik, 2015), terhadap program pengembangan kapasitas SDM pengendalian karhutla, berdasarkan dimensi input, proses dan outputoutcome.

Melalui penerapan metode dan instrumen yang telah terbangun berdasarkan kriteriakriteria pada pilar/dimensi penting program pengembangan kapasitas SDM pengendalian karhutla (selanjutnya dinamai Rapfire), penelitian ini akan memberikan gambaran kondisi keberlanjutan program pengembangan kapasitas SDM pengendalian karhutla yang selama ini telah berjalan. Penelitian ini juga mengidentifikasi faktor-faktor pengungkit skor keberlanjutan, yang direkomendasikan sebagai prioritas utama intervensi kebijakan untuk mempertahankan atau meningkatkan keberlanjutan program pengembangan kapasitas SDM pengendalian karhutla.

\section{METODE}

Terdapat banyak metode yang telah dibangun untuk menilai keberlanjutan suatu program. Dalam penelitian ini keberlanjutan program pengembangan kapasitas SDM pengendalian karhutla didekati dengan pendekatan Multidimensional Scaling (MDS). MDS merupakan sebuah metode penilaian yang bersifat diagnostik, yaitu menilai kecenderungan keberlanjutan unit analisis yang dikaji. Selain menggambarkan indikasi tingkat keberlanjutan suatu program, analisis ini juga menghasilkan informasi atribut-atribut sensitif yang merupakan faktor pengungkit bagi status keberlanjutan unit analisis atau program, yang dapat dijadikan sebagai prioritas utama untuk dilakukan intervensi kebijakan dalam mempertahankan atau meningkatkan status keberlanjutan program. Namun karena hanya bersifat diagnostik, metode MDS tidak sampai tingkat menghasilkan rekomendasi praktis tertentu sebagai bentuk intervensi kebijakan yang disarankan.

Dalam pendekatan MDS, objek atau unit analisis yang diteliti digambarkan sebagai titik dalam ruang multidimensi yang diukur kesamaan, kedekatan atau keterkaitannya, berdasarkan jarak antar titik nya (Borg, Groenen, \& Mair, 2013). Teknik statistik dalam MDS melakukan transformasi multi dimensi menjadi dimensi yang lebih rendah (Fauzi \& Anna, 2005). Beberapa penelitian membuktikan penggunaan MDS yang dipadukan dengan Rapfish menghasilkan hasil yang lebih stabil dibandingkan metode Multi-variate analysis lainnya seperti factor analysis dan Multi-Attribute Utility Theory (Pitcher \& Preikshot, 2001), dan memiliki keunggulan karena dapat menangani data nominal atau ordinal serta tidak memerlukan normalitas (Ariyani et al., 2015). 
Gambaran dan status keberlanjutan pada metode MDS, diperoleh melalui pengolahan data dengan membangun dan menggunakan analisis Rapfire. Rapfire dibangun dengan memodifikasi program Rapfish. dengan mengubah dimensi, atribut/peubah dan indikator berdasarkan permasalahan terkait, dalam hal ini yaitu program pengembangan kapasitas SDM pengendalian karhutla. Rapfish pertama kali dibangun oleh Fisheries Center, University of British Columbia, dengan memiliki prinsip dasar yaitu: 1) metode penilaian status keberlanjutan suatu unit analisis yang bersifat cepat dengan mengacu pada atribut-atribut terkait yang mudah diskoring; 2) atribut-atribut dapat diganti atau diredefinisi sesuai kebutuhan dan informasi yang tersedia (Pitcher \& Preikshot, 2001); 3) metode pegambilan keputusan yang bersifat multrikriteria dan berskala multi dimensi; 4) penggunaan metode ordinasi dalam penentuan status keberlanjutan(Fauzi \& Anna, 2005). Rapfire mendasarkan operasinya pada prinsip-prinsip Rapfish tersebut, melalui redefinisi dimensi dan atribut, untuk dapat diterapkan dalam mengevaluasi status keberlanjutan program pengembangan kapasitas SDM pengendalian karhutla. Rapfire akan menghasilkan gambaran mengenai status atau kondisi keberlanjutan program pengembangan kapasitas SDM pengendalian karhutla yang selama ini telah berjalan, serta faktor-faktor sensitif atau penting yang mempengaruhi status keberlanjutan tersebut. Informasi yang dihasilkan tersebut dapat dijadikan sebagai bahan pertimbangan dalam menentukan arah intervensi kebijakan yang diperlukan untuk efektivitas dan keberlanjutan program ke depan.

Teknik ordinasi dilakukan melalui penghitungan jarak euclidian (d) antar titik/objek dalam ruang berdimensi n, dengan menggunakan persamaan (Pitcher \& Preikshot, 2001):

$$
\sqrt{d=\left(x_{1}-x_{2}\right)^{2}+\left(y_{1}-y_{2}\right)^{2}+\left(z_{1}-z_{2}\right)^{2}+\cdots}
$$

Dimana xi, yi, dan zi, merupakan unit/objek yang dianalisis keberlanjutannya dalam garis euclidius. Konfigurasi objek dalam MDS diproxy dengan meregresikan jarak euclidius (dij) dari titik i ke titik j dari titik acuan dij dengan menggunakan rumus regresi berikut (Pitcher \& Preikshot, 2001):

$$
d_{i j}=\alpha+\beta d_{i j}+\varepsilon ; \varepsilon=\text { error }
$$

Dalam megresikan persamaan digunakan algoritma ALSCAL, dimana regresi diiterasi sedemikian rupa sehingga menghasilkan nilai error terkecil. Menurut (Kavanagh \& Pitcher, 2004), penggunaan algoritma ALSCAL dilakukan untuk mendapatkan intercept pada persamaan menjadi nol $(a=0)$, sehingga menghasilkan persamaan:

$$
\boldsymbol{d}_{i j}=\boldsymbol{\beta} d_{i j}+\varepsilon
$$

Metode ALSCAL mengoptimasi jarak kuadrat (square distance $=$ dijk) terhadap data kuadrat (titik asal $=$ dijk) dalam tiga dimensi $(\mathrm{i}, \mathrm{j}, \mathrm{k}$ ) yang disebut dengan $S$-Stress. Model yang baik ditunjukkan dengan nilai stress yang lebih kecil dari 0,25 (Fauzi \& Anna, 2005). Nilai stress didapatkan melalui persamaan:

$$
\text { Stress }=\sqrt{\sum \frac{1}{m}{ }_{\mathbf{k}=1}^{\mathbf{m}}\left[\frac{\sum \sum\left(d_{i j}-o_{i j}\right)^{2}}{\sum \sum 0^{4}{ }_{i j k}}\right]}
$$
berikut:

Dalam penelitian ini, analisis Rapfire dilakukan melalui beberapa tahapan sebagai

1. Menentukan dimensi, mereviu atribut dan mendefinisikan unit program pengembangan kapasitas SDM pengendalian karhutla yang akan dianalisis. Data dan informasi diperoleh melalui studi literatur dan wawancara mendalam dengan responden pakar. 
2. Melakukan penilaian/skoring atribut dengan melakukan pembobotan melalui perbandingan berpasangan (pairwise comparison) antar dimensi berdasarkan skala kepentingan. Skoring melibatkan responden pakar bidang pengembangan kapasitas SDM pengendalian karhutla.

3. Menganalisis nilai skor dari masing-masing atribut dengan MDS dengan melakukan analisis ordinasi menggunakan software Program $\mathrm{R}$ (perangkat lunak terbuka). Dalam analisis ordinasi, status keberlanjutan masing-masing program disimulasikan menjadi sebuah titik yang ditempatkan pada urutan yang terukur dan dijangkar oleh titik-titik referensi, berdasarkan skala good/baik dan bad/buruk. Hasil analisis masing-masing dimensi akan menunjukkan tingkat status keberlanjutan dimensi tersebut. Setelah setiap dimensi dianalisis, kemudian dilanjutkan dengan analisis perbandingan tingkat keberlanjutan antar dimensi, yang dapat dilakukan dan divisualisasikan melalui diagram layang-layang (kite diagram).

4. Melakukan analisis sensitivitas (leverage analysis) dan analisis Monte Carlo. Leverage analysis digunakan untuk menentukan atribut-atribut sensitif atau disebut juga sebagai faktor pengungkit keberlanjutan. Analisis Monte Carlo digunakan untuk antisipasi aspek ketidakpastian, dan untuk memperhitungkan ketidakpastian dengan mengevaluasi dampak kesalahan acak akibat minimnya informasi, pengaruh keragaman skor akibat perbedaan opini atau penilaian, kesalahan dalam data entry (termasuk data hilang), stabilitas proses analisis MDS yang berulang-ulang, dan tingginya stress (incomplete covergence) yang dilakukan melalui pendekatan simulasi. Model yang dibangun telah mengantisipasi toleransi nilai stress sebesar $25 \%$.

Penelitian ini dilakukan pada bulan Agustus sampai dengan Desember 2017, melibatkan proses wawancara mendalam dengan sejumlah pakar. Wawancara dilakukan di tempat kerja responden dan atau sesuai perjanjian yang disepakati. Responden pakar yang terlibat dalam penelitian ini terdiri atas 7 (tujuh) responden pakar terpilih, khususnya praktisi yang selama ini terlibat dalam program pengembangan kapasitas SDM pengendalian karhutla. Responden pakar dipilih berdasarkan latar belakang pendidikan dan atau pekerjaan yang sesuai, pengalaman yang cukup, dan atau keterlibatannya terkait permasalahan yang dibahas. Selain terlibat dalam penentuan dimensi, atribut/peubah dan indikator keberlanjutan untuk membangun Rapfire, responden pakar juga terlibat dalam penilaian status keberlanjutan melalui pengisian kuisioner Rapfire yang telah dibangun.

\section{HASIL DAN PEMBAHASAN}

\section{Dimensi, Atribut dan Kriteria}

Berdasarkan studi literatur dan terkonfirmasi melalui wawancara mendalam dengan responden pakar, ditetapkan tiga dimensi evaluasi yaitu Input, Proses dan Outputoutcome. Penggunaan ketiga pilar tersebut sebelumnya telah juga digunakan oleh Bushnel (1990) dalam membangun model untuk mengevaluasi pelatihan/pengembangan SDM. Dalam hal analisis keberlanjutan menggunakan pendekatan MDS, ketiga pilar ini juga sebelumnya telah dipakai oleh Ariyani et al. (2015) dalam mengevaluasi program pengentasan kemiskinan menggunakan metode Rappoverty. Atribut dan kriteria masingmasing dimensi yang ditetapkan adalah sebagaimana pada tabel 1 berikut. 
Tabel 1. Dimensi, Atribut dan Kriteria Evaluasi Program Pengembangan Kapasitas SDM Pengendalian Karhutla

\begin{tabular}{ll}
\hline Dimensi & \multicolumn{2}{c}{$\begin{array}{c}\text { Dimensi dan Atribut } \\
\text { Atribut }\end{array}$} \\
\hline 1. & Sistem rekrutmen $(1,2,3,7,8)$ \\
& \\
2. & $\begin{array}{l}\text { Kelengkapan Sarpras / Peralatan } \\
(1,2,3,4,5,7)\end{array}$ \\
3. & Sumber pendanaan $(1,2,3,5)$ \\
4. & Sistem penganggaran $(1,2,3,5)$
\end{tabular}

Input 5. Kurikulum/pedoman pelatihan $(1,4,5,3,8)$

6. Kelembagaan pengelola program $(1,3,4,8)$

7. Pendapatan personil $(1,3)$

8. Status kepegawaian personil $(1,4,8)$

1. Pendekatan perencanaan program $(1,3,5,7)$

2. Training Need Assessment $(1,3,6,7)$

3. Sistem insentif $(1,3)$

4. Materi kegiatan pelatihan/ Bimtek $(1,3,4,5,8,10)$

Proses

5. Intensitas pelatihan/Bimtek $(1,5,7)$

6. Monitoring dan evaluasi program $(1,3,5,7)$

7. Sistem Database untuk mobilisasi personil $(1,3)$

1. Jumlah personil dalkarhutla terlatih $(1,3,4)$

2. Pengetahuan dan keterampilan teknis personil dalkarhutla $(1,2,3,4,5,7$,

3. Kesadaran/motivasi personil dalkarhutla $(1,3,7,9)$

Output/

Outcome 4. Kerja sama dan kekompakan tim $(1,2,3,7,10)$

5. Pengakuan/sertifikasi kompetensi $(1,11,12)$

6. Dampak program dalam peningkatan kesejahteraan personil $(1,5)$

Buruk Baik Kriteria

$0 \quad 10 \quad 0-2$ (Tidak ada); 3-5 (Ada, tidak diimplementasikan); 6-8 (Ada, tidak sepenuhnya diimplementasikan); 9-10 (Ada, diimplementasikan penuh/selektif)

$0 \quad 10 \quad$ 0-2 (Tidak ada); 3-5 (Kurang); 6-8 (Cukup); 9 10 (Lengkap)

$0 \quad 10 \quad$ 0-2 (Tidak ada); 3-6 (1-2 sumber); 7-10 (>2 sumber)

$0 \quad 10 \quad$ 0-2 (Anggaran tersedia tidak menentu); 3-6 (Tersedia anggaran saat dinilai perlu); 7-10 (Dianggarkan rutin/bagian dari kinerja utama organisasi)

$0 \quad 10 \quad 0-2$ (Tidak ada); 3-5 Ada bersifat umum/general dan atau insidentil (6-8 Ada dan berjenjang); 9-10 (Ada berbasis standar kompetensi)

$0 \quad 10 \quad$ 0-2 (Tidak ada); 3-6 (Ada bersifat umum); $7-$ 10 (Ada bersifat khusus)

$0 \quad 10 \quad 0-2$ (Tidak ada); 3-5 (Ada bersifat insidentil/keproyekan); 6-8 (Penghasilan tetap dan merata/seragam); 9-10 (Penghasilan tetap berdasar jabatan/beban kerja)

10 0-2 (Tidak terikat/bersifat voluntary); 3-6 (Kontrak/dengan perjanjian kerja); 7-10 (pegawai tetap)

10 0-2 (Bersifat topdown); 3-6 (Perpaduan topdown dan bottom-up); 7-10 (Bersifat partisipatif)

10 0-2 (Tidak dilakukan); 3-6 (Dilakukan sekalikali); 7-10 (Dilakukan rutin/terprogram)

10 0-2 (Tidak ada); 3-6 (Ada bersifat general); 7 10 (Ada dan berstruktur)

10 0-2 (General); 3-6 (Spesifik/substantif); 7-10 (Berbasis kompetensi)

10 0-2 (Tidak pernah/hanya sekali); 3-6 (Jarang);

7-10 (Sering/terprogram)

0

10 0-2 (Tidak dilakukan); 3-6 (Dilakukan tapi tidak rutin); 7-10(Dilakukan rutin/terprogram)

0

10 0-2 (Tidak ada); 3-6 (Ada tapi tidak lengkap dan terbaharu); 7-10 (Ada, lengkap, terbaharui)

10 0-2 (Kurang); 3-6 (Cukup); 7-10 (Lebih dari cukup)

10 0-2 (Kurang); 3-6 (Cukup/memadai); 7-10 (Kompeten)

10 0-2 (Kurang); 3-6 (Cukup); 7-10 (Tinggi/ berpartisipasi aktif)

10 0-2 (Tidak terorganisir); 3-6 (Rendah); 7-10 (Kompak dan terorganisir dengan baik)

10 0-2 (Tidak ada); 3-6 (SK dan sertifikat pelatihan); 7-10 (Sertifikat kompetensi)

$0 \quad 10$ 0-2 (Tidak ada); 3-5 (Rendah); 6-8 (Sedang); 9-10 (Tinggi) 


\begin{tabular}{|c|c|c|c|c|c|}
\hline \multicolumn{3}{|r|}{ Dimensi dan Atribut } & \multicolumn{3}{|r|}{ Kriteria } \\
\hline Dimensi & No & Atribut & Buruk & Baik & Skor \\
\hline & 7. & $\begin{array}{l}\text { Dampak program terhadap } \\
\text { efektifitas penanganan kejadian } \\
\text { karhutla }(1,2,5)\end{array}$ & 0 & 10 & $\begin{array}{l}\text { 0-2 (Tidak ada); 3-5 (Rendah); 6-8 (Sedang); } \\
\text { 9-10 (Tinggi) }\end{array}$ \\
\hline & 8. & $\begin{array}{l}\text { Dampak program terhadap } \\
\text { partisipasi masyarakat sekitar } \\
(1,2,3,5)\end{array}$ & 0 & 10 & $\begin{array}{l}\text { 0-2 (Tidak ada); 3-5 (Rendah); 6-8 (Sedang); } \\
\text { 9-10 (Tinggi) }\end{array}$ \\
\hline
\end{tabular}

Sumber: 1) FGD dan reponden pakar; 2) UNDP (2009); 3) IEGKE (2008); 4) KLHK (2016); 5) Bushnel (1990); 6) Barbazette (2006); 7) Kirkpatrick dan Kirkpartrick (2009); 8) Ditjen PHKA (2014); 9) Van der Locht, Van Dam, \& Chiaburu (2013); 10) Monroe et al. (2013); 11) Tragel dan Shemilina (2015); 12) Aranega (2014).

\section{Analisis Status Keberlanjutan}

Skoring/penilaian atribut diterapkan pada 8 (delapan) objek atau unit analisis program pengembangan kapasitas SDM pengendalian karhutla yang selama ini telah berjalan di Indonesia. Unit program pengembangan kapasitas SDM non masyarakat terdiri atas Manggala Agni (KLHK), Brigade Karhutla Balai Besar Taman Nasional Gunung Gede Pangrango (BBTNGP), Brigade Karhutla KPH Lakitan Sumatera Selatan (Pemerintah Daerah), FERT- Fire Emergency Response Team (PT RAPP). Sementara program dengan kepesertaan masyarakat adalah Kelompok Tani Peduli Api (binaan Kementerian Pertanian), Masyarakat Peduli Api (MPA binaan KLHK/Pusat), MPA-BBTNGP (binaan BBTNGP), dan MPA-RAPP (binaan PT RAPP). Unit-unit tersebut dipilih setelah mempertimbangkan unsur kepesertaan (masyarakat/volunter dan non masyarakat/kontrak), fasilitator (pemerintah dan non-pemerinah), dan tingkat kerawanan (rawan dan non rawan).

Hasil analisis ordinasi Rapfire terhadap 8 program pengembangan kapasitas SDM Pengendalian Karhutla pada masing-masing dimensi menghasilkan skor keberlanjutan masing-masing unit analisis/program pengembangan kapasitas SDM pengendalian karhutla sebagaimana termuat dalam Tabel 2. serta tervisualisasikan pada gambar 1 (dimensi Input), gambar 2 (dimensi proses) dan gambar 3 (dimensi output-outcome).

Tabel 2. Skor Keberlanjutan Program Pengembangan Kapasitas SDM Pengendalian Karhutla Berdasarkan Hasil Analisis Ordinasi

\begin{tabular}{lllll}
\hline \multirow{2}{*}{ No. } & \multirow{2}{*}{ Unit Analisis } & \multicolumn{3}{c}{ Skor Keberlanjutan pada dimensi: } \\
\cline { 3 - 4 } & & Input & Proses & Output \\
\hline 1 & Manggala Agni & 72.56887 & 46.55149 & 72.78856 \\
2 & MPA & 51.40052 & 34.3062 & 43.54534 \\
3 & KTPA & 42.08334 & 24.85141 & 41.18675 \\
4 & Brigade BBTNGP & 56.45105 & 43.2158 & 61.98344 \\
5 & MPA_BBTNGP & 39.61139 & 30.11557 & 53.04124 \\
6 & KPH Lakitan & 57.33794 & 44.67568 & 72.40353 \\
7 & FERT & 80.53462 & 67.83069 & 79.0068 \\
8 & MPA_RAPP & 62.59859 & 53.05336 & 60.12528 \\
\hline
\end{tabular}

Sumber: hasil pengolahan Rapfire

Hasil analisis ordinasi Rapfire terhadap 8 program pengembangan kapasitas pengendalian karhutla sebagaimana tersaji pada gambar 1, 2, dan 3 di atas menggambarkan sejauh mana kecenderungan keberlanjutan masing-masing program pada masing-masing dimensi input, proses dan output-outcome. Semakin ke kanan atau semakin mendekati titik G (good) maka dapat dinilai program tersebut cenderung berkelanjutan, demikian sebaliknya, semakin ke kiri atau mendekati titik B (bad), kecenderungannya adalah tidak berkelanjutan. 


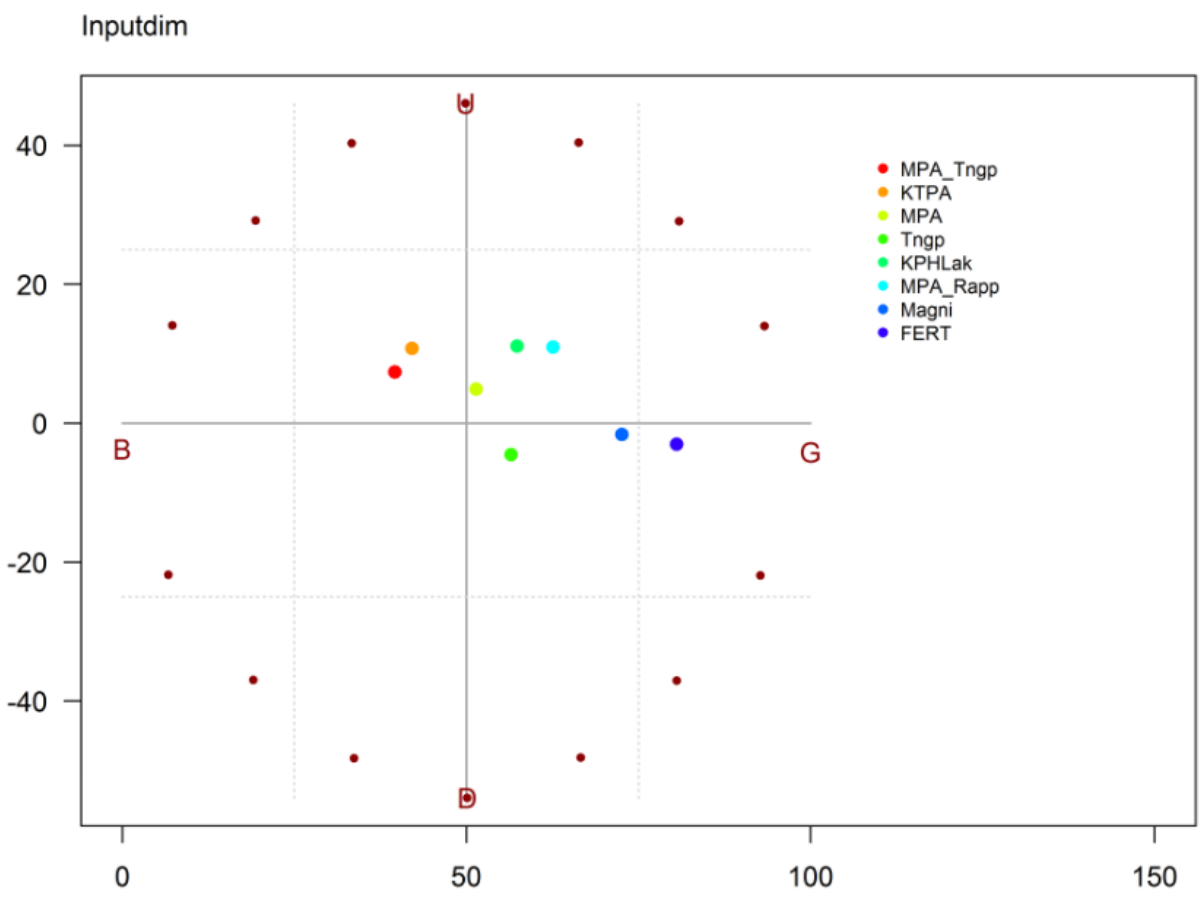

Gambar 1. Status Keberlanjutan Dimensi Input

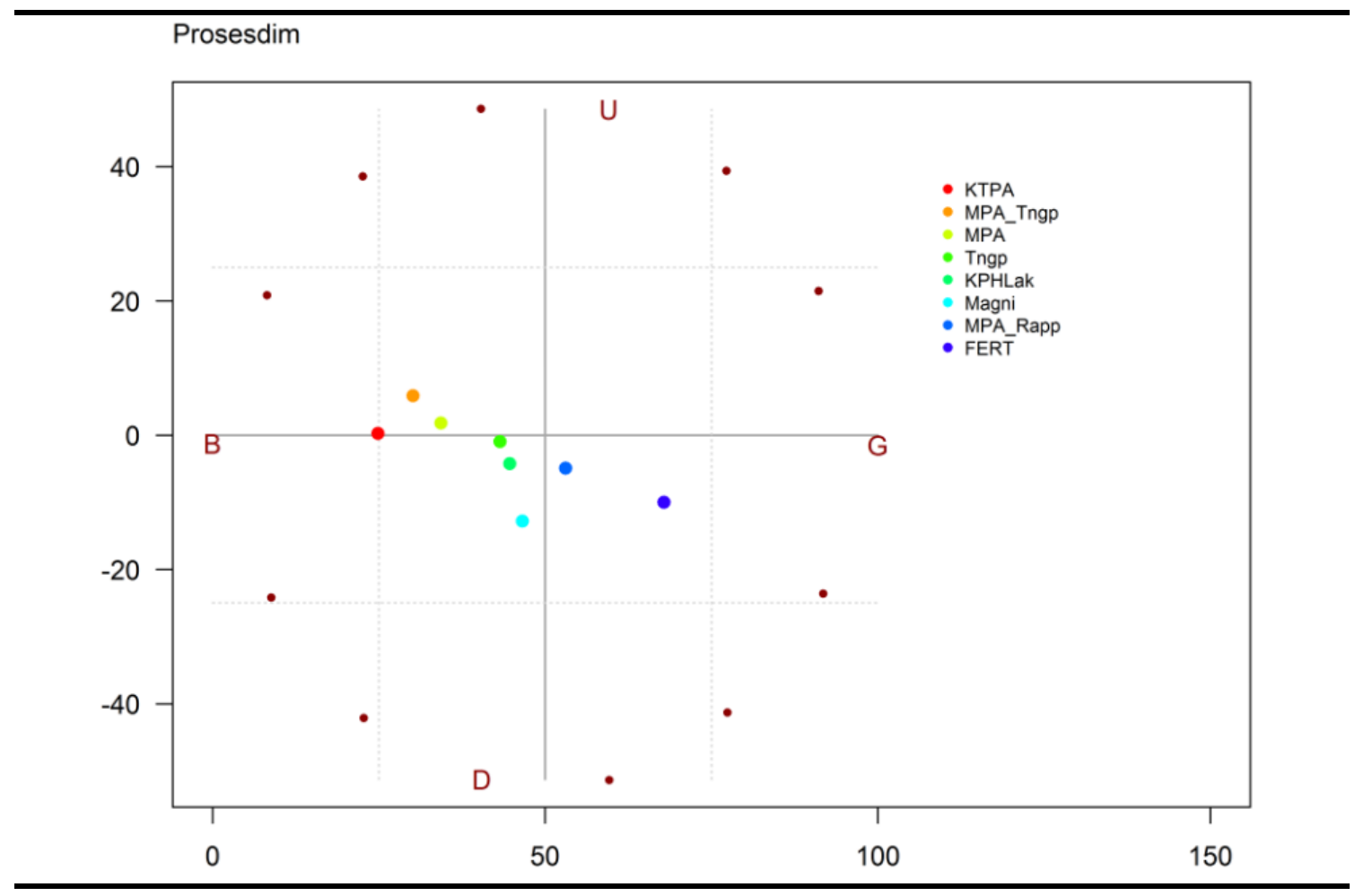

Gambar 2. Status Keberlanjutan Dimensi Proses 
Outputdim

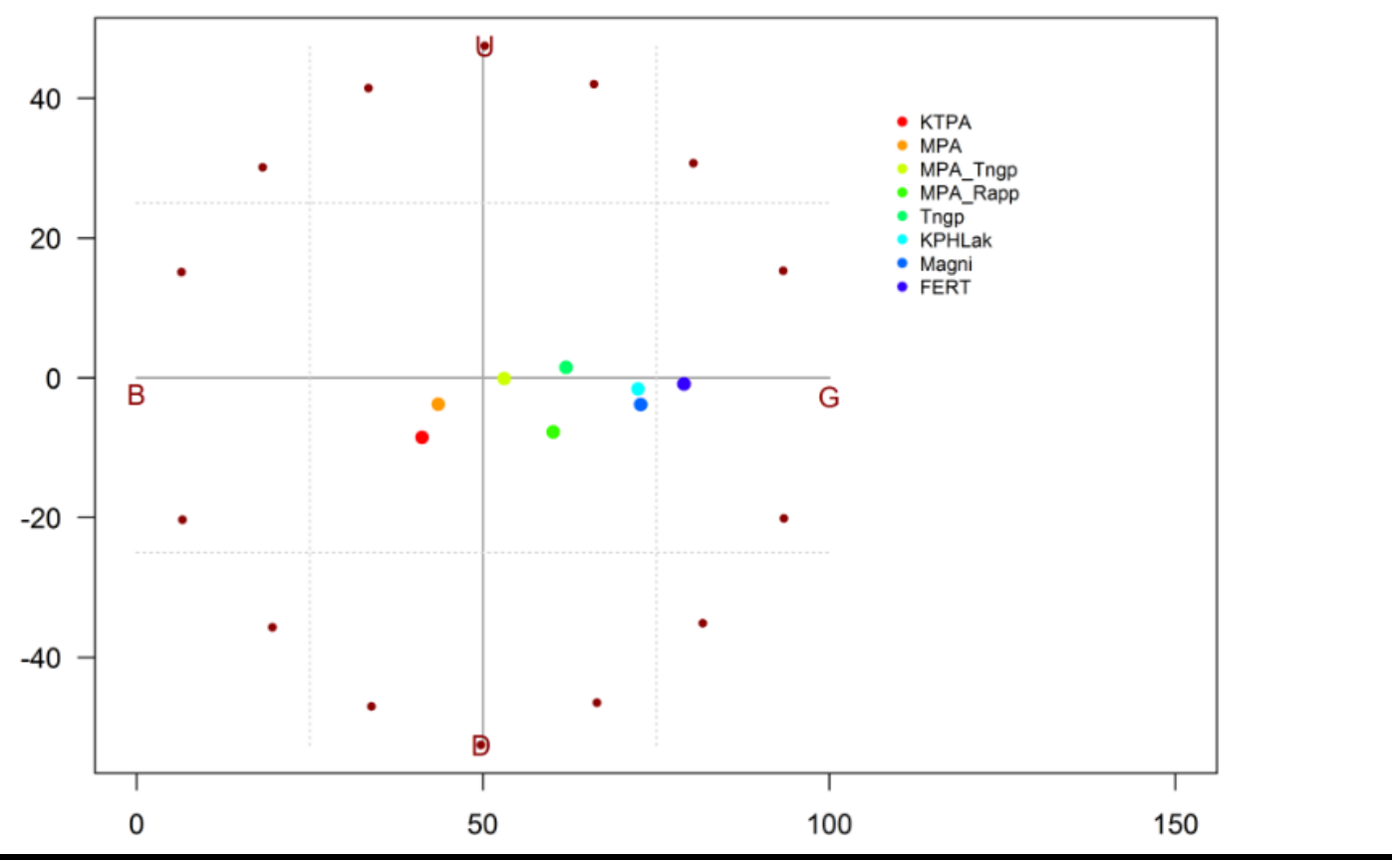

Gambar 3. Status Keberlanjutan Dimensi Output-Outcome

Dari ketiga gambar tersebut terlihat bahwa keberlanjutan program pengembangan kapasitas SDM pengendalian karhutla bervariasi. Program dengan kepesertaan sukarelawan masyarakat lainnya (KTPA, MPA, MPA-Tngp) umumnya memiliki kecenderungan tidak berkelanjutan. Dari ketiga dimensi keberlanjutan, program KTPA merupakan program yang memiliki tingkat keberlanjutan yang terendah dibanding program lainnya. Rendahnya tingkat keberlanjutan program KTPA yang pembentukannya diinisiasi Kementerian Pertanian ini kemungkinan disebabkan karena terhentinya penganggaran kegiatan (insentif) dari Kementerian Pertanian pada tahun 2016 dan 2017.

Rendahnya tingkat keberlanjutan beberapa program pengembangan kapasitas dari unsur masyarakat ini mengkonfirmasi penelitian sebelumnya bahwa SDM mayarakat belum sepenuhnya teroptimalkan dalam kegiatan upaya pengendalian karhutla. Hal tersebut dapat disebabkan kurang optimalnya pelibatan masyarakat dalam perencanaan (Muttaqin et al., 2015), koordinasi antar lembaga (Friskarini \& Kasnodihardjo, 2013; Sukrismanto et al., 2011), kurangnya pembinaan dan pelatihan (Evayanti \& Zulkarnaini, 2014; Saharjo \& Putera, 2015), dan lemahnya kelembagaan (Imanudin, Armanto, \& Probowati, 2015).

Program pengembangan kapasitas SDM unsur masyarakat yang difasilitasi pusat (KTPA dan MPA) cenderung kurang berkelanjutan kemungkinan karena jumlahnya yang banyak dan tersebar hingga ke pelosok sehingga menyulitkan pengelolaan dan pengendaliannya. Namun demikian bukan berarti jumlah yang terbatas dan jangkauan relatif kecil akan menjamin keberlanjutan yang baik, hal tersebut setidaknya terlihat dari perbedaan status keberlanjutan 2 program SDM masyarakat yang difasilitasi unit pengelola berbeda yaitu MPA yang difasilitasi BBTNGP yang menunjukkan kecenderungan tidak berkelanjutan, dan MPA yang difasilitasi PT. RAPP (MPA-RAPP) yang cenderung berkelanjutan.

Kecenderungan ketidakberlanjutan program MPA_Tngp kemungkinan karena wilayah TNGP memang bukan merupakan daerah rawan kebakaran, sehingga kurang memiliki kesiapsiagaan dalam mengantisipasi karhutla. Walaupun tidak intens, karhutla 
senantiasa terjadi di dalam atau daerah sekitarnya dalam luasan terbatas. Kebakaran relatif besar di dalam kawasan TNGP terakhir terjadi pada tahun 1997 meliputi 307,6 hektar luas lahan terbakar (BTNGP, 1999).

Kecenderungan keberlanjutan Program MPA-RAPP diyakini berkaitan dengan salah satu program unggulan RAPP yakni Program Desa Bebas Api (Fire Free Village Program/FFVP) yakni program pendekatan multi pemangku kepentingan untuk mencegah karhutla, dimana MPA merupakan komponen kelembagaan pengendalian karhutla tingkat desa. Program FFVP meliputi beberapa elemen kegiatan termasuk termasuk pelatihan dan insentif.

Sementara itu, Fire Emergency Response Team (FERT) yang merupakan brigade pengendalian karhutla yang dikelola oleh PT. RAPP terlihat secara konsisten memiliki kecenderungan berkelanjutan yang tertinggi dari ketiga dimensi. Tim ini dinilai cukup profesional, dimana masing-masing anggota memilki kemampuan spesifik dan ditunjang pola pelatihan yang terspesialisasi. FERT juga dilengkapi fasilitas dan peralatan pendukung pengendalian karhutla yang lengkap termasuk helikopter, waterboat, menara kamera tersembuyi (CCTV) dan drone guna melakukan pendeteksian ke area yang sulit ditembus.

Secara multi dimensi, indeks keberlanjutan secara multidimensi masing-masing program pada setiap dimensi diperlihatkan pada gambar 4.

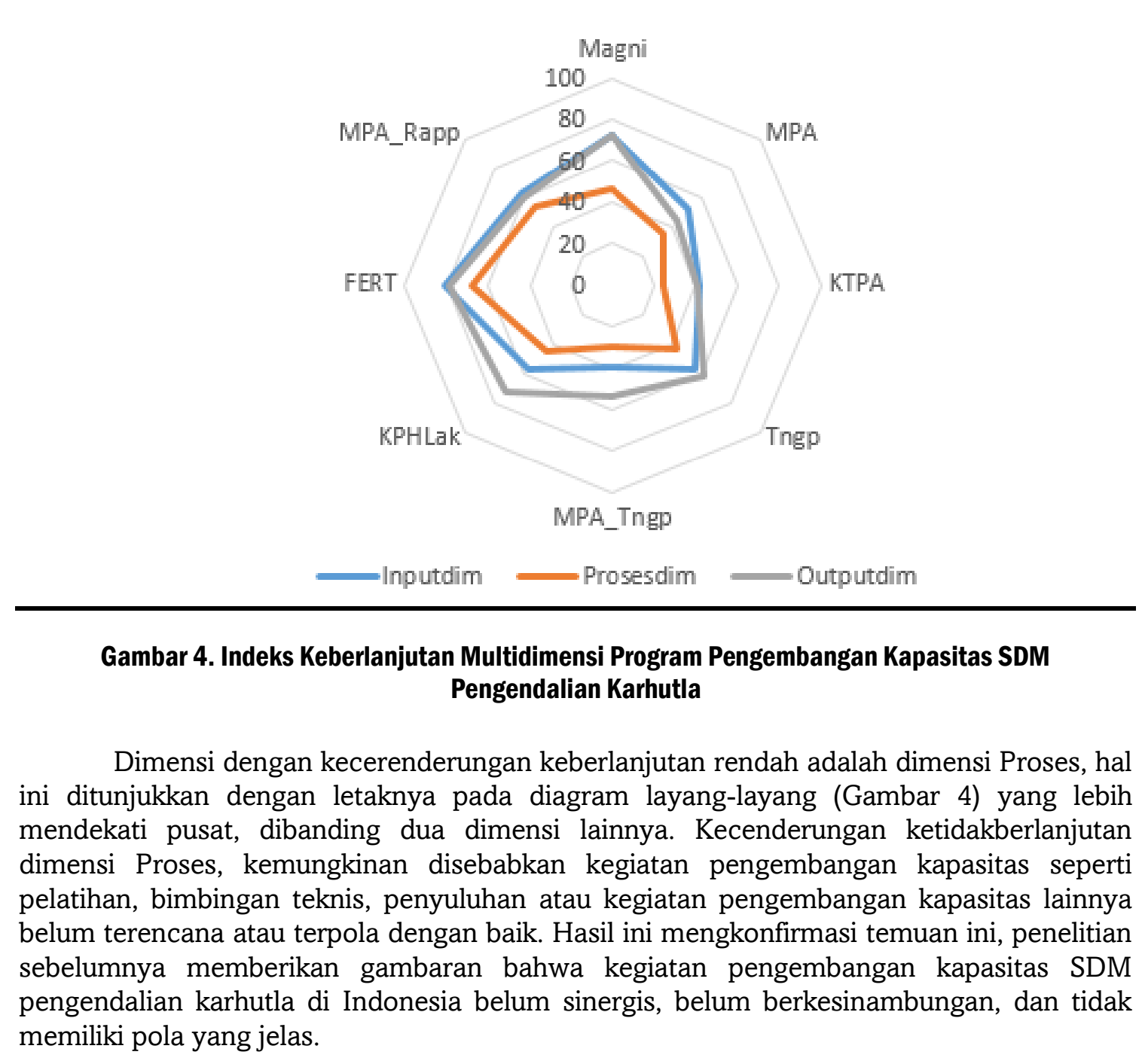




\section{Analisis Sensitivitas}

Analisis sensitivitas (leverage analysis) digunakan untuk menilai tingkat sensitivitas masing-masing atribut terhadap skor keberlanjutan. Atribut-atribut yang memiliki tingkat sensitivitas relatif lebih tinggi dari yang lainnya atau disebut juga sebagai faktor pengungkit, berperan paling dominan dalam menentukan indeks keberlanjutan unit analisis, dan karenanya perlu diprioritaskan untuk dilakukan intervensi kebijakan dalam rangka mempertahankan atau meningkatkan status keberlanjutan dari unit-unit analisis. Tingkat sensitivitas masing-masing atribut terhadap skor keberlanjutan berdasarkan analisis leverage dimuat dalam Tabel 3.

Tabel 3. Tingkat Skor Keberlanjutan Program Pengembangan Kapasitas SDM Pengendalian Karhutla Berdasarkan Hasil Analisis Ordinasi

\begin{tabular}{|c|c|c|}
\hline \multicolumn{2}{|r|}{ Dimensi dan Atribut } & \multirow{2}{*}{ Nilai Sensitivitas } \\
\hline Dimensi & No. Atribut & \\
\hline \multirow{8}{*}{ Input } & 1. Sistem rekrutmen & 2.880009 \\
\hline & 2. Kelengkapan Sarpras/ Peralatan & 2.213012 \\
\hline & 3. Sumber pendanaan & 2.332983 \\
\hline & 4. Sistem penganggaran & 2.572318 \\
\hline & 5. Kurikulum/pedoman pelatihan & 1.582827 \\
\hline & 6. Kelembagaan pengelola program & 2.805612 \\
\hline & 7. Pendapatan personil & 1.631826 \\
\hline & Status kepegawaian personil & 2.252007 \\
\hline \multirow{7}{*}{ Proses } & 1. Pendekatan perencanaan program & 1.528487 \\
\hline & 2. Training Need Assessment & 1.698827 \\
\hline & 3. Sistem insentif & 1.24271 \\
\hline & 4. Materi kegiatan pelatihan/ Bimtek & 2.342642 \\
\hline & 5. Intensitas pelatihan/Bimtek & 2.317491 \\
\hline & Monitoring dan evaluasi program & 1.574429 \\
\hline & 7. Sistem Database untuk mobilisasi personil & 1.627622 \\
\hline \multirow{8}{*}{$\begin{array}{l}\text { Output/ } \\
\text { Outcome }\end{array}$} & 1. Jumlah personil dalkarhutla terlatih & 0.728337 \\
\hline & 2. Pengetahuan dan keterampilan teknis personil dalkarhutla & 1.465617 \\
\hline & 3. Kesadaran/motivasi personil dalkarhutla & 2.384933 \\
\hline & 4. Kerja sama dan kekompakan tim & 1.815331 \\
\hline & Pengakuan/sertifikasi kompetensi & 1.400325 \\
\hline & Dampak program dalam peningkatan kesejahteraan personil & 2.146046 \\
\hline & Dampak program terhadap efektifitas penanganan kejadian karhutla & 1.453902 \\
\hline & 8. Dampak program terhadap partisipasi masyarakat sekitar & 0.962662 \\
\hline
\end{tabular}

Sumber: hasil pengolahan Rapfire

Untuk lebih mudah memahami dan membandingkan kondisi sensitivitas masingmasing atribut, nilai sensitivitas pada Tabel 3 divisualisasikan pada gambar 5 . Hasil Analisis leverage menggambarkan tingkat sensitivitas atribut terhadap skor keberlanjutan, dan bukan menggambarkan tingkat keberlanjutan dari atribut itu sendiri.

Dari gambar 5 terlihat bahwa secara keseluruhan, tiga besar atribut yang paling sensitif atau paling menentukan skor keberlanjutan program pengembangan kapasitas SDM pengendalian karhutla adalah atribut sistem rekrutmen, atribut kelembagaan pengelola program dan atribut sistem penganggaran. Ketiga atribut tersebut menjadi faktor utama pengungkit keberlanjutan, baik dalam kelompok dimensi input maupun secara keseluruhan. Hasil ini memberi penjelasan bahwa untuk mempertahankan atau meningkatkan status keberlanjutan program pengembangan kapasitas SDM pengendalian karhutla, maka intervensi kebijakan sebaiknya diprioritaskan pada dimensi input, baik berupa penguatan ataupun perbaikan sistem rekrutmen, kelembagaan pengelola program dan sistem penganggaran. Dikaitkan dengan temuan sebelumnya terkait tingkat keberlanjutan pada dimensi proses yang cenderung rendah dibanding dimensi input dan 
output-outcome, temuan ini menegaskan bahwa kondisi kecenderungan aktivitas kegiatan yang minim, maka sistem rekrutmen, pengelola program dan sistem penganggaran berperan penting dalam rangka pencapaian output-outcome sesuai yang diharapkan.

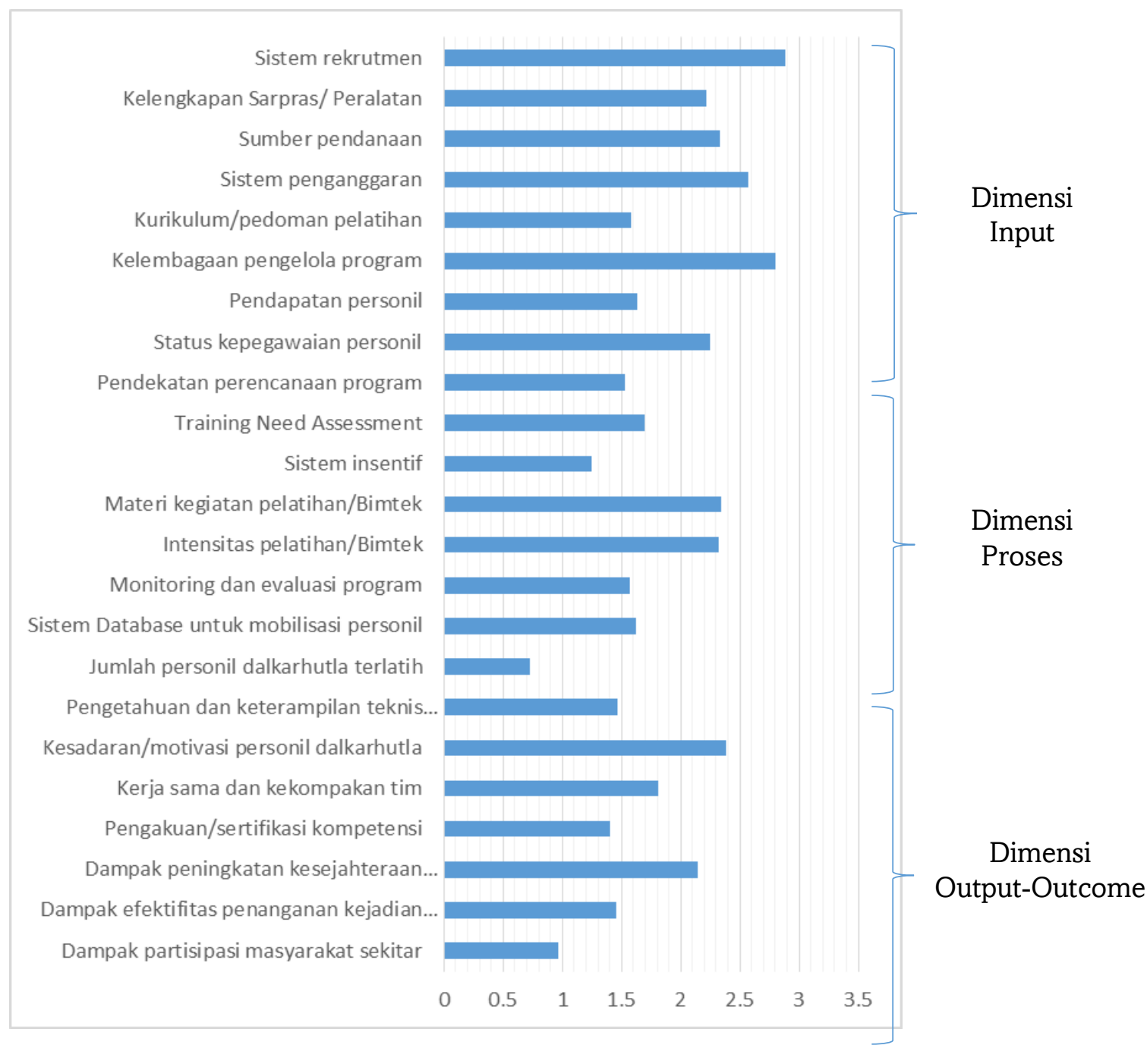

\section{Gambar 5. Analisis Leverage}

Sistem rekrutmen dapat berfungsi sebagai saringan awal untuk menjaring personil yang memiliki potensi kapabilitas dan integritas sesuai kebutuhan lembaga/organisasi. Penggunaan strategi perekrutan dan perekrutan yang efektif dapat menciptakan iklim yang tepat di mana individu akan dapat bekerja secara produktif dan berkembang secara profesional, dan membantu individu menyesuaikan budaya organisasi dan tetap bertahan dalam keanggotaan organisasi (Hedge, Carolina, \& Borman, 2012). Sistem rekrutmen juga dapat meningkatkan keterikatan/kekompakan antar individu (Pringgabayu \& Kusumastuti, 2016). Rekrutmen dan seleksi dapat mengacu kepada kebutuhan berdasarkan analisis pekerjaan (job analysis) (Morgeson et al., 2012). Kualitas suatu organisasi/pengelola berpengaruh terhadap keberlanjutan program pengembangan kapasitas SDM, karena fungsinya tidak sekedar bagaimana meningkatkan pengetahuan dan keterampilan individu, namun juga terkait sistem insentif dan kapasitas mengelola (governance) (OECD, 2006). 
Sistem penganggaran mengacu pada proses di mana organisasi akan merencanakan kegiatan keuangannya di masa depan (UNDP, 2009), dengan mengestimasi biaya setiap fase pelatihan atau pengembangan kapasitas SDM, yaitu fase biaya pengembangan, fase biaya pelaksanaan, dan fase biaya pemeliharaan (Nilson, 2003).

Diluar dimensi Input, atribut materi kegiatan pelatihan/bimtek, atribut intensitas pelatihan/bimtek dan atribut Training Need Assesment merupakan faktor pengungkit utama dalam dimensi Proses. Materi kegiatan bernilai sensitif karena transfer pengetahuan dan keterampilan yang tidak tepat sasaran akan mubazir karena berpotensi tidak dapat diaplikasikan di lapangan. Hal tersebut mengkonfirmasi hasil penelitian Eriksson (2009) yang menunjukkan bahwa pemberian materi yang tidak sesuai akan mengakibatkan respon dan kesiapsiagaan yang salah dari masyarakat saat menyikapi situasi yang darurat, yang umumnya bersifat bersifat spesifik. Materi yang cenderung bersifat umum/general seyogyanya dikurangi dan dapat lebih diarahkan pada materi-materi yang bersifat tematik dan lokal sesuai kebutuhan, sehingga dapat lebih aplikatif di lapangan. Training Need Assessment (TNA) dilakukan sebagai pendekatan untuk lebih memastikan atau menjamin materi pengembangan kapasitas tepat sasaran dan sesuai kebutuhan. Disamping itu, TNA mengumpulkan informasi terkait alasan pelaksanaan pelatihan, siapa yang akan terlibat dalam pelatihan, bagaimana mengatasi rendahnya kinerja, cara terbaik pelaksaannya, serta waktu dan tempat terbaik pelaksanaan pelatihan (Barbazette, 2006). TNA juga dapat diarahkan untuk dapat menyerap nilai-nilai dalam masyarakat atau kearifan lokal, untuk dapat dipertimbangkan dalam menentukan materi ataupun metode pelatihan. Integrasi kearifan lokal dan pengetahuan modern dapat berperan besar dalam meningkatkan ketahanan masyarakat dalam menghadapi bencana (Depari, 2015).

Dalam dimensi Output-Outcome, yang menjadi faktor pengungkit utama adalah kesadaran/motivasi personil, dampak program dalam peningkatan kesejahteraan personil, serta kerja sama dan kekompakan tim. Hal ini mengkonfirmasi temuan di lapangan bahwa efektivitas pengendalian karhutla di lapangan tidak semata-mata ditentukan oleh keterampilan personil dalam mengendalikan kebakaran, namun hal yang lebih penting adalah kesadaran/motivasi personil. Hal ini tampak lebih dominan untuk program dengan kepesertaan anggota masyarakat, dengan peran utamanya sebagai agent of change (agen perubahan) di masyarakat. Sebelum dapat mengajak masyarakat lainnya, kesadaran dan motivasi yang tinggi harus dimiliki terlebih dahulu oleh personil SDM pengendalian karhutla.

\section{Analisis Ketidakpastian}

Untuk mengantisipasi aspek ketidakpastian dalam analisis Rapfire, dilakukan analisis Monte Carlo dengan metode "scatter plot". Analisis Monte Carlo mengantisipasi aspek ketidakpastian yang bisa disebabkan kesalahan skoring akibat minimnya informasi, keragaman skoring akibat perbedaan penilaian, kesalahan entry data, dan tingginya nilai stress (Fauzi \& Anna, 2005). Analisis Monte Carlo mengukur dampak dari kesalahan acak melalui metode simulasi dengan menunjukkan perubahan ordinansi pada masing-masing dimensi. Simulasi analisis Monte Carlo yang dilakukan melalui 100 kali pengulangan (Gambar 6) mengkonfirmasi bahwa model status keberlanjutan program pengembangan kapasitas SDM pengendalian karhutla yang telah diuraikan sebelumnya telah dapat mengantisipasi random error. Hal tersebut terlihat dari plot yang berpola sama dengan sebaran titik-titik terkonsentrasi pada titik asal (tidak keluar jangkar). Dengan hasil analisis tersebut, maka dapat disimpulkan bahwa model telah cukup baik dan tidak memerlukan perbaikan. 


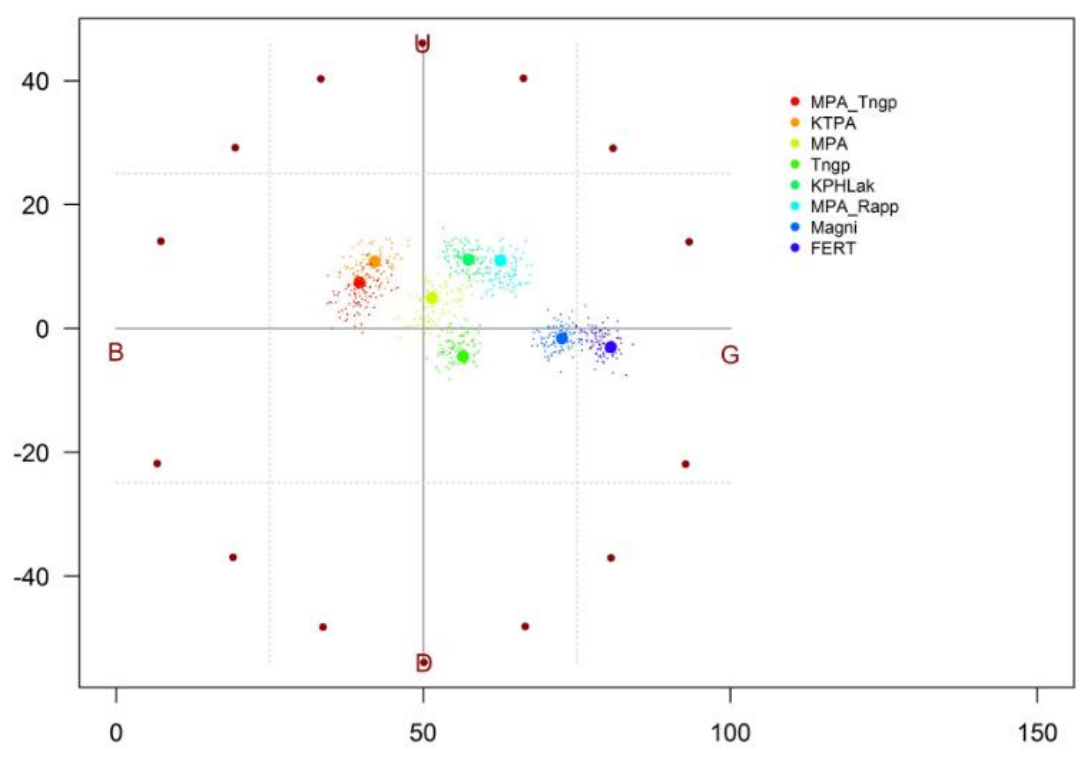

Gambar 6. Hasil Analisis Monte Carlo Dimensi Input

\section{KESIMPULAN}

Berdasarkan penerapan metode Rapfire, penelitian ini menyimpulkan secara umum program pengembangan kapasitas SDM pengendalian karhutla dengan kepesertaan masyarakat cenderung menunjukkan hasil kurang berlanjut bila dibanding program dengan kepesertaan non-masyarakat (tenaga kontrak/pegawai). Faktor pengungkit utama status keberlanjutan program berada pada dimensi input, yaitu atribut sistem rekrutmen, kelembagaan pengelola program, dan sistem penganggaran. Dalam dimensi proses, atribut yang menjadi faktor pengungkit utama adalah materi pelatihan, intensitas pelatihan dan Traning Need Assessment, sedangkan dalam dimensi output-outcome, atribut-atribut yang menjadi faktor pengungkit utama adalah kesadaran/motivasi personil, dampak program bagi kesejahteraan personil dan kerja sama/kekompakan tim. Atribut-atribut yang menjadi faktor pengungkit direkomendasikan untuk mendapatkan prioritas kebijakan dalam rangka mempertahankan atau meningkatkan status keberlanjutan program pengembangan kapasitas SDM pengendalian karhutla,

\section{UCAPAN TERIMA KASIH}

Para penulis mengucapkan terima kasih kepada pihak-pihak yang turut berperan dalam penyelesaian penelitian ini, yang tidak dapat kami sebutkan satu persatu. Terima kasih juga khususnya Kementerian Lingkungan Hidup dan Kehutanan cq. Pusat Diklat SDM Lingkungan Hidup dan Kehutanan sebagai pihak penyandang dana utama penelitian ini.

\section{DAFTAR PUSTAKA}

Akbar, A., Hadi, R., \& Sabarudin, M. S. (2011). Studi Sumber Penyebab Terjadinya Kebakaran dan Respon Masyarakat dalam Rangka Pengendalian Kebakaran Hutan Gambut di Areal Mawas Kalimantan Tengah. Jurnal Penelitian Tanaman Hutan, 8(5), 287-300.

Aránegaa , S. (2014). Competences for employability: How can they be developed and assessed in initial training? Procedia - Social and Behavioral Sciences, 139, 366-372. http://doi.org/10.1016/j.sbspro.2014.08.015 
Ariyani, N., Fauzi, A., Juanda, B., \& Beik, I. S. (2015). Evaluasi Program Pengentasan Kemiskinan Menggunakan Metode Rapfish. Jurnal Ekonomi \& Kebijakan Publik, 6(2), 181-197.

Barbazette, J. (2006). Training Needs Assessment; Methods, Tools, and Techniques. (R. Taff, Ed.). San Fransisco: Pfeifer.

Borg, I., Groenen, P. J. F., \& Mair, P. (2013). Applied Multidimensional Scaling. London: Springer.

BTNGP, [Balai Taman Nasional Gunung Gede Pangrango]. (1999). Statistik Balai Taman Nasional Gunung Gede Pangrango Tahun 1998. Cianjur.

Bushnel, D. S. (1990). Input, Process, Output: A Model for Evaluating Training. Training \& Development Journal, (March), 41.

CaDRi, [Capacity for Disaster Reduction Initiative]. (2012). Basics of Capacity Development for Disaster Risk Reduction. Geneva: International Environment House II.

Cattau, M. E., Harrison, M. E., Shinyo, I., Tungau, S., Uriarte, M., \& Defries, R. (2016). Sources of anthropogenic fire ignitions on the peat-swamp landscape in Kalimantan, Indonesia. Global Environmental Change, 39, 205-219. http://doi.org/10.1016/j.gloenvcha.2016.05.005

Darwiati, W., \& Tuheteru, F. D. (2010). Forest Fire Impact on the Growth of Vegetation. Tekno Hutan Tanaman, 3(1), 29-35.

Depari, C. D. A. (2015). Kearifan Lokal Dalam Penataan Ruang Kawasan Bencana Vulkanik Studi Kasus: Desa Kepuharjo Cangkringan. Tata Loka, 3(1), 21-36.

Ditjen PHKA. Pembentukan dan Pembinaan Masyarakat Peduli Api (2014). Indonesia: Peraturan Direktorat Jenderal Perlindungan Hutan dan Konservasi Alam.

Eriksson, K. (2009). Knowledge transfer between preparedness and emergency response : a case study. Disaster Prevention and Management, 18(2), 162-169. http://doi.org/10.1108/09653560910953234

Evayanti, T., \& Zulkarnaini. (2014). Partisipasi Organisasi Masyarakat Peduli Api (MPA) Terhadap Pencegahan dan Pengendalian Kebakaran Hutan dan Lahan di Kabupaten Pelalawan. Jurnal Ilmu Lingkungan, 8(1), $1-11$.

Fauzi, A., \& Anna, S. (2005). Pemodelan Sumber Daya Perikanan dan Kelautan. PT Gramedia Pustaka Utama.

Friskarini, K., \& Kasnodihardjo. (2013). Persepsi Petugas Sektor Terkait Tentang Kebakaran Hutan dan Upaya Penanggulangannya di Provisi Jambi. Jurnal Ekologi Kesehatan, 12(3), 243-252.

Harun, S. (2016). Koordinasi antara Pemerintah Provinsi Riau Dan Pemerintah Kabupaten Rokan Hilir dalam Menangani Kebakaran Hutan dan Lahan (Karhutla) di Rokan Hilir Tahun 2010-2013. Jom FISIP, 3(1), $1-13$.

Hedge, J. W., Carolina, N., \& Borman, W. C. (2012). Personnel Recruitment, Selection, and Turnover. In G. Salvendy (Ed.), Handbook of Human Factors and Ergonomics (4th ed., pp. 475-489). New Jersey: John Wiley \& Sons, Inc.

IEGKE, [Independent Evaluation Group Knowledge Programs and Evaluation Capacity Development]. (2008). Using Training to Build Capacity for Development An Evaluation of the World Bank's Project-Based and WBI Training. Washington DC.

Imanudin, M. S., Armanto, M. E., \& Probowati, D. (2015). Strategi Pengendalian Kebakaran Hutan Terpadu dalam Upaya Mendukung Program Zero Asap di Sumatera Selatan (pp. 1-12).

Kavanagh, P., \& Pitcher, T. J. (2004). Implementing Microsoft Excel Software For Rapfish: A Technique for The Rapid Appraisal of Fisheries Status. (Vol. 12). Vancouver.

Khalwani, K. M., Bahruni, \& Syaufina, L. (2015). Nilai Kerugian dan Efektivitas Pencegahan Kebakaran Hutan gambut (Studi Kasus di Taman Nasional Sebangau Provinsi Kalimantan Tengah). Risalah Kebijakan Pertanian Dan Lingkungan, 2(3), 214-229.

Kirkpatrick, D. L., \& Kirkpatrick, J. D. (2009). Evaluating Training Programs; The Four Levels (3rd ed.). Oakland: Berret_Koehler.

KLHK, [Kementerian Lingkungan Hidup dan Kehutanan]. Rencana Strategis Kementerian Lingkungan Hidup dan Kehutanan (2015). Indonesia: Peraturan Menteri Lingkungan Hidup dan Kehutanan Nomor P.39/menlhk-Setjen/2015.

KLHK, [Kementerian Lingkungan Hidup dan Kehutanan]. Pengendalian Kebakaran Hutan dan Lahan (2016). Indonesia: Peraturan Menteri Lingkungan Hidup dan Kehutanan Nomor P.32/MenLHK/Setjen/Kum.1/3/2016.

Meiwanda, G. (2016). Kapabilitas Pemerintah Daerah Provinsi Riau : Hambatan dan Tantangan Pengendalian Kebakaran Hutan dan Lahan. Jurnal Ilmu Sosial Dan Ilmu Politik, 19(3), 251-263. 
Monroe, M. C., Agrawal, S., Jakes, P. J., Linda, E., Nelson, K. C., \& Sturtevant, V. (2013). Identifying Indicators of Behavior Change: Insights From Wildfire Education Programs. The Journal of Environmental Education, 44(3), 37-41. http://doi.org/10.1080/00958964.2012.746277

Morgan, J. (2016). Children and Youth Services Review Participation, empowerment and capacity building : Exploring young people 's perspectives on the services provided to them by a grassroots NGO in subSaharan Africa. Children and Youth Services Review, 65, 175-182. http://doi.org/10.1016/j.childyouth.2016.04.012

Morgeson, F. P., Lansing, E., Campion, M. A., Lafayette, W., Bruning, P. F., Lafayette, W., \& Design, J. (2012). Job and Team Design. In G. Salvendy (Ed.), Handbook of Human Factors and Ergonomics (4th ed., pp. 442-474). New Jersey: John Wiley \& Sons, Inc.

Muttaqin, Husin, T., \& Safrida. (2015). Peran Masyarakat dalam Penanggulangan Bencana Kebakaran Hutan (Studi Kasus Kebakaran Hutan wilayah Unit Pelaksana Teknis Dinas Kehutanan Aceh pada Kesatuan Pengelolaan Hutan Taman Hutan Raya Pocut Meurah Intan). Jurnal Ilmu Kebencanaan, 2(1), 28-34.

Nilson, C. (2003). How to Manage Training; A Guide to Design and Delivery for High Performance (3rd ed.). New York: Amacom.

Nurdianto, K., Mardhiansyah, M., \& Oktorini, Y. (2016). Pengetahuan Masyarakat Terhadap Kebijakan Pemerintah dalam Penanganan Bencana Kebakaran Hutan dan Lahan di Sekitar Taman Nasional Tesso Nilo. Jom Faperta, 3(1), 1-7.

OECD, [Organisation for Economic Co-operation and Development]. (2006). The Challenge of Capacity Development: Working Towards Good Practice. Paris: OECD Publishing.

Pitcher, T. J., \& Preikshot, D. (2001). Rapfish : a rapid appraisal technique to evaluate the sustainability status of Fisheries. Fisheries Research, 49, 255-270.

Pringgabayu, D., \& Kusumastuti, D. (2016). Peningkatan Keterikatan Karyawan melalui SIstem Rekrutmen, Desain Pekerjaan, Kompensasi dan Iklim Organisasi dengan Lingkungan Kerja sebagai Variabel Moderasi. Bina Ekonomi, 20(2), 163-178.

Qodriyatun, S. N. (2014). Kebijakan Penanganan Kebakaran Hutan dan Lahan. Info Singkat Kesejahteraan Sosial, VI(06), 9-12.

Saharjo, B. H. (2016). Pengendalian Kebakaran Hutan dan atau Lahan di Indonesia. Bogor: IPB Press.

Saharjo, B. H., \& Putera, M. I. (2015). Pembentukan Masyarakat Peduli Api Sebagai Strategi Pengendalian Kebakaran Hutan di Hutan Pendidikan Holcim Cibadak Sukabumi. Jurnal Silvikultur Tropika, 6(3), 179183.

Sukrismanto, E., Alikodra, H. S., \& Saharjo, B. H. (2011). Hubungan Antar Organisasi dalam Sistem Pengorganisasian Pengendalian Kebakaran Hutan/Lahan di Indonesia. Jurnal Penelitian Hutan Tanaman, 8(3), 169-177.

Syaufina, L. (2008). Kebakaran Hutan dan Lahan di Indonesia. Malang: Bayu Media Publishing.

Tragel, M. V, \& Shemilina, E. M. (2015). The Model of Competences of Specialists Working in Training Groups as Integration of Professional Knowledge, Skills, Values and Beliefs. Procedia - Social and Behavioral Sciences, 186, 1101-1108. http://doi.org/10.1016/j.sbspro.2015.04.051

UNDP, [United Nations Development Programs]. (2009). Capacity Development: A UNDP Primer. New York: UNDP Bureau for Development Policy.

Van der Locht, M., Van Dam, K., \& Chiaburu, D. S. (2013). Getting the most of management training : the role of identical elements for training transfer. Personnel Review, 42(4), 422-439. http://doi.org/10.1108/PR-05-2011-0072 